\title{
Secuencias de una guerra: Representación de la violencia en los llanos orientales en el largometraje Canaguaro $(1981)^{1}$ Sequences of a war: Representation of violence in the eastern plains in the Canaguaro feature film
}

Doi: $10.25100 /$ hye.v17i17.10592

Artículo recibido: 03-09-2020 Artículo aceptado: 12-06-2021

\author{
Jairo Alberto Tamí Rincón \\ Universidad Industrial de Santander, Bucaramanga. \\ Correo electrónico: jatari94@gmail.com \\ Orcid: 0000-0003-0943-0114

\section{Helwar Hernando Figueroa Salamanca} \\ Profesor titular Universidad Industrial de Santander. \\ Correo electrónico: helwarff@uis.edu.co \\ Orcid: 0000-0002-4310-9124
}

Forma de citar este artículo: Tamí Rincón, Jairo Alberto y Figueroa Salamanca, Helwar Hernando. "Secuencias de una guerra: Representación de la violencia en los llanos orientales en el largometraje Canaguaro (1981)”. Historia y Espacio. Vol. 17. n57 (2021): 253-284. Doi:10.25100/hye.v17i17.10592

1 Artículo de investigación derivado del proyecto Representaciones cinematográficas de la violencia política en Colombia: Análisis de tres producciones significativas (1981-1985), escrito en el marco del Taller sobre el Estudio del Conflicto y los Movimientos Sociales en Colombia, adscrito al Grupo de Investigaciones Históricas sobre el Estado Nacional Colombiano (GIHENC) avalado por la Universidad Industrial de Santander. 


\section{Resumen}

El largometraje Canaguaro - dirigido por el chileno Dunav Kuzmanich - es analizado apelando a la historiografía especializada sobre el período histórico recreado en el filme, y en el cual la Violencia en los Llanos Orientales de Colombia es el eje temático que soporta su narrativa fílmica. Para ello se utilizó el instrumento de análisis secuencial de contenido fílmico, lo que permitió dividir el largometraje en secuencias significativas relacionadas con el tratamiento dado a la violencia. La selección de las secuencias se basó en la lectura crítica del guion por medio de conceptos como violencia política, Estado, guerrillas e historiografía sobre la violencia. A partir de la investigación se puede concluir que la película, en términos generales, realiza una interpretación sintética de la Violencia, que puede extrapolarse a otros contextos; igualmente, su narrativa privilegia al pueblo llanero, representado en la lucha y resistencia popular del protagonista, víctima de una guerra frente a un Estado que solo muestra su cara represiva.

Palabras clave (fuente: tesauro de la Unesco) Cine; cinematografía; violencia; análisis de contenido; Colombia.

\section{Abstract}

The feature film Canaguaro (1981), directed by the Chilean Dunav Kuzmanich, is analyzed cinematographically through the use of specialized historiography on the historical period recreated in the film, where Violence in the Eastern Plains of Colombia is the thematic axis that supports its filmic narrative. For this, a Sequential Analysis of Film Content instrument was used, by means of which the feature film was divided into specific sequences in the treatment of violence. The selection of the sequences was based on a critical reading of the script through concepts such as political violence, the State, guerrillas and historiography on violence. From the research it can be concluded that the film, in general terms, makes a synthetic interpretation of "La Violencia" that can be extrapolated to other contexts; likewise, its narrative privilege the people of the plains, portrayed as the fight and popular resistance of the protagonist, victim of a war against a State that only shows its repressive facet.

Keywords (Source: Unesco thesaurus) Cinema; Cinematography; violence; content analysis; Colombia. 


\section{Jairo Alberto Tamí Rincón - Helwar Hernando Figueroa Salamanca \\ Secuencias de una guerra: Representación de la violencia en los llanos orientales en el largometraje Canaguaro (1981)}

\section{Introducción}

Colombia, a comienzos de la década de 1980, atravesaba por una ebullición social sin precedentes, frente a la cual el Estado solo atinaba a responder por medio de la represión y la persecución a las diversas manifestaciones y organizaciones sociales que se vieron obligadas a incluir entre sus reivindicaciones el derecho a la vida y la defensa de los derechos humanos. Se trataba de una política estatal de dominación basada en los lineamientos de la lucha contrainsurgente irradiada desde los Estados Unidos para todo el continente americano, asimilada muy bien por las elites locales y nacionales identificadas con la lucha antisubversiva, y que por esos mismos años iniciaban la organización y financiación de ejércitos privados². Prueba de ello es el Estatuto de Seguridad Nacional, o Decreto 1923 de 1978, expedido por el presidente Julio César Turbay (1978-1982), una especie de síntesis de los numerosos estados de sitio que lo precedieron desde los inicios de la guerra civil de mediados del siglo XX ${ }^{3}$, conocida eufemísticamente como la Violencia ${ }^{4}$.

2 Vilma Franco Restrepo, Orden contrainsurgente y dominación (Bogotá: Siglo del Hombre, 2009), 85-140; Mauricio Romero Vidal, Paramilitares y autodefensas 1982-2003 (Bogotá: Planeta, 2003), 117-158; Mauricio Archila Neira, "Colombia 1975-2000: de crisis en crisis. Contexto”, en 25 años de luchas sociales en Colombia: 1975-2000, ed. Helena Gardeazábal Garzón (Bogotá: Ediciones Anthropos Ltda., 2002), 16.

3 Darío Villamizar Herrera, Las guerrillas en Colombia. Una historia desde los orígenes hasta los confines (Bogotá: Penguin Ramdom House Grupo Editorial, 2017), 44.

4 La Violencia se conoció como el período comprendido entre 1946 y 1964, en el cual el país se sumió en una guerra civil que confrontó a los partidos hegemónicos de la época, pero que nunca se reconoció como tal y que todavía hoy algunos estudios no la definen como tal y la prefieren dejar "sin nombre”. Si bien se consideró en un principio que los móviles principales de la confrontación estaban arraigados en los intereses partidistas con el tiempo se ha conocido el período de la Violencia como un tiempo de violencias múltiples con diferentes causas que no necesariamente pueden atribuirse a la histórica confrontación entre los par- 
No obstante, la persecución a los movimientos sociales, existían expresiones artísticas y culturales alternativas opuestas al autoritarismo y a la represión oficial, una válvula de escape y a la vez eje aglutinador de los sectores artísticos críticos de la sociedad 5 .

En ese contexto, numerosos artistas nacionales pertenecientes a diferentes disciplinas - artes plásticas, caricaturistas, cineastas - materializaron en sus obras el descontento general ${ }^{6}$ que persistió durante todo el Frente Nacional (1958-1974) y en los años posteriores. En el cine, si bien Colombia presentaba un atraso con respecto a la producción del Cono Sur - donde se había afianzado una corriente cinematográfica contestataria-, se produjeron largometrajes en consonancia con la ola latinoamericana de denuncia de los conflictos sociales y políticos, principalmente en la segunda mitad del siglo XX. Aunque autores como Juana Suárez señalan que el cine nacional no representó necesariamente un desafío político al establecimiento ${ }^{7}$ sí aparecieron producciones —entre los años sesenta y ochenta - elaboradas desde un imaginario diferente en torno a las violencias del siglo XX, con variedad de actores y contextos ${ }^{8}$. De tal manera que la cinematografía, aunque reducida en su producción ${ }^{9}$, tuvo la capacidad

tidos. La Violencia es uno de los problemas sociales más desarrollados en la historiografía colombiana, para una visión general se recomiendan, entre otros, los balances de Gonzalo Sánchez y Ricardo Peñaranda (1987), Carlos Miguel Ortiz (1993), Fernán González, Ingrid Bolívar y Teófilo Vázquez (2003) y Juan Carlos Villamizar (2018).

5 Paulo León Palacios, “Una experiencia estética de lo político: el teatro en Bogotá durante los años 1960 y 1970”, Historelo vol. 9, n. 17 (2017), https://doi.org/10.15446/historelo. v9n17.54732.

${ }^{6}$ María Barón Pino y Camilo Ordóñez Robayo, "Editoriales visuales, publicidad gráfica y cine al final del Frente Nacional”, Cuadernos de música, artes visuales y artes escénicas vol. 6, n.․ 2 (2011): 123, https://doi.org/10.11144/Javeriana.mavae6-2.evpg.

7 Juana Suárez, Sitios de contienda: producción cultural colombiana y discurso de la violencia (Madrid: Iberoamericana, 2010), 48.

8 A pesar de que el propósito de este escrito es analizar cómo es representada la violencia bipartidista en el filme Canaguaro, apelando principalmente a la historiografía sobre la violencia y el contexto, se debe señalar que existen diversos escritos sobre la historia del cine colombiano o el análisis cinematográfico que pueden ayudar a tener una mejor percepción del cine como denuncia. De estas obras sobresalen: Hernando Martínez (1978), Luisa Acosta (1998), Enrique Pulecio (1999), Juana Suárez $(2009,2010)$ y Martín Agudelo (2016). Para una historiografía sobre el cine en Colombia revisar: Oswaldo Osorio (2009), Luisa Acosta (2009) y Andrés Villegas y Santiago Alarcón (2017).

9 Suárez, Sitios de contienda, 57; Gonzalo Castellanos, Cinematografía en Colombia: tras las huellas de una industria (Bogotá: Icono Editorial, 2014), 34; Angélica Mateus Mora, "Un cineasta 
de denunciar la violencia política, guerrillera y narcotraficante; por cierto, volviendo muchas veces a los acontecimientos nueveabrileños, vistos en las diversas formas artísticas como una especie de mito fundador de la Violencia, el cual marcó la vida nacional desde esas fechas hasta la actualidad ${ }^{10}$.

Este es el caso del largometraje Canaguaro (1981), dirigido por el chileno Dunav Kuzmanich ${ }^{11}$, que recrea los últimos años de la confrontación bipartidista colombiana desarrollada en los Llanos Orientales, y cuya trama es protagonizada por un comandante guerrillero y los hombres bajo su mando, quienes tienen la misión de recoger en la frontera con Venezuela un envío de armas para continuar la guerra contra el gobierno conservador del depuesto presidente Laureano Gómez. Durante su desarrollo se observa cómo la guerra golpeó y transformó los modos de vida de sus protagonistas. De ahí que el filme comience con los motines y saqueos ocurridos el 9 de abril de 1948 en Bogotá (el Bogotazo), imágenes que muestran su destrucción, la sublevación del pueblo, la quema del tranvía, de varios templos y del Palacio de Gobierno; y, sobre todo, los amotinamientos que terminaron en cientos de muertos tirados en las calles. Con una voz en off — de Juan Harvey Caicedo, la voz que animó desde los años setenta hasta su muerte el espíritu llanero-, se describe la matanza, la represión y la persecución del Gobierno conservador a los liberales; y la respuesta por

chileno. Kuzmanich y el cine de la Violencia en Colombia”, Revista CUHSO, 14 (2007): 39 , http://dx.doi.org/10.7770/cuhso-V14N1-art262. Según Juana Suárez, la búsqueda por afianzar el cine nacional y equipararlo a las industrias de México, Cuba y el Cono Sur, llevó a la creación de la Compañía de Fomento Cinematográfico (Focine) que operó entre 1978 y 1993. Antes de ser disuelta, menciona, el cine alcanzó cierta regularidad en comparación a los años anteriores. Resalta Gonzalo Castellanos que durante su funcionamiento se financiaron 45 largometrajes y cerca de 64 documentales. No obstante, Canaguaro empezó a rodarse meses antes de la creación de la institución, de manera que su financiamiento provino inicialmente de un préstamo del Fondo Nacional de Desarrollo (Fonade), y el Banco Corporación Financiera Popular. El actor Alberto Jiménez, mediante su productora, negocia el préstamo inicial con Fonade, solo en las últimas fases el largometraje recibió estímulos de parte de Focine.

${ }^{10}$ Juana Suárez, Cinembargo Colombia: ensayos críticos sobre cine y cultura (Cali: Editorial Universidad del Valle, 2009), 58.

${ }^{11}$ Dunav Kuzmanich fue un cineasta chileno exiliado en Colombia luego del golpe de Estado a Salvador Allende el 11 de septiembre de 1973. Comprometido con las luchas sociales y abiertamente de izquierda, su propuesta cinematográfica en Colombia se centró en evidenciar la violencia y las inequidades de la sociedad. Debido a esto la censura política acompañó su carrera cinematográfica por largo tiempo, no obstante, su cine se sobrepuso y se considera fundamental dentro del cine político y social en el país. 
parte del pueblo ante la persecución, la muerte y la pérdida de una esperanza de liberación que les ofrecía Gaitán, su caudillo.

1953, la única fecha clara en el filme, será un año de esperanza para este pueblo y sus sueños revolucionarios. El lugar elegido para esta revolución social fue los Llanos Orientales. Así, del blanco y negro con el que se pinta la guerra y del fuego que consume Bogotá, se pasa a un fotograma protagonizado por un grupo de hombres a caballo, con fusil terciado y sombrero alón, tan clásicos en la fotografía sobre la Revolución mexicana. Con la voz de Caicedo se pasa a la música llanera, ambientadora del color cálido de las sabanas llaneras, tan característica del paisaje sociocultural del mundo llanero de Colombia y Venezuela. El sonido del arpa dramatiza un paisaje de sabana lleno de verde, morichales, ríos; y, en ese momento, de hombres en armas que le cantan al paisaje, al caballo y a la mujer llanera. Ay mi llanura, de Arnulfo Briceño, el conjunto Alma Llanera y su canto al llano acompañarán hasta el final de la recreación cinematográfica la odisea de Canaguaro, quien durante todo el filme busca unas armas quiméricas; y, a la vez, serán el fondo musical de un filme marcado por los corridos y el contrapunteo llanero ${ }^{12}$.

La producción cinematográfica sobre la violencia en Colombia es asimétrica, a diferencia, por ejemplo, del cine de la Revolución mexicana, donde gran parte de su producción fue extraída directamente del campo de batalla ${ }^{13}$. Un desfase temporal que nos cuestiona sobre la representación de la historia en el cine. Ciertamente, es imposible experimentar el pasado; sin embargo, por la fuerza de la imagen, del sonido y la recreación en sí, el cine se constituye en una de las mejores herramientas artísticas para acercarnos un poco a é ${ }^{14}$. Un escenario ficticio en el cual el cineasta monta un texto recurriendo a los elementos sociales

${ }^{12}$ Suárez, Cinembargo Colombia, 77. Según Juana Suárez, la intención de Kuzmanich en relación con la inclusión de la música llanera en Canaguaro tenía el propósito de equiparar la producción de este filme con los westerns y la tradición de las películas sobre las revoluciones rusa y mexicana, donde el elemento musical o de cultura popular es central; para el caso mexicano es más evidente cómo los corridos hacen parte de la narrativa fílmica y del heroísmo de sus personajes. Kuzmanich intenta hacerlo en su filme con la música llanera y su homenaje al paisaje sabanero, pero también en el contrapunteo de las coplas llaneras que hacen alusión a la política y la injusticia social.

${ }^{13}$ Fernando Fabio Sánchez y Gerardo García Muñoz, La luz y la guerra. El cine de la Revolución mexicana (México D. F.: Dirección de Publicaciones del Consejo Nacional para la Cultura y las Artes, 2010), 17.

${ }^{14}$ Peter Burke, Visto y no visto: el uso de la imagen como documento histórico (Barcelona: Editorial Crítica, 2005), 98. 
o inmateriales que le permiten poner en escena un punto de vista con el objeto de ganar verosimilitud. Al respecto, Ferro distingue dos tipos de cine histórico: el positivista, centrado en la reconstrucción erudita y fidedigna con el pasado representado, una perspectiva hoy cuestionada puesto que lograr una certeza plena es imposible, además toda mirada o reconstrucción tiene una carga subjetiva. Y el cine histórico, en el cual la ideología (dominante o no) influye abiertamente en el hecho que se reconstruye. En relación con este último, Ferro señala que este tipo de cine no logra recrear o no le interesa el contexto histórico y menos asumir una visión crítica de los hechos representados ${ }^{15}$.

Así, la relación entre la Historia y el cine tiende a complejizarse, puesto que la pregunta acerca de si estamos frente a unos hechos representados fidedignamente siempre estará presente; al mismo tiempo que nos interrogamos sobre las motivaciones, consecuencias y matices que el director pone en escena. Resulta imposible lograr una representación fílmica de los hechos al pie de la letra - las investigaciones históricas también pueden tener falencias en ese sentido-; sin embargo, vale la pena preguntarse cómo el cine filtra, deforma, forma y recrea los acontecimientos que la memoria de los observadores después graba. Al igual que otras narraciones verbales o iconográficas, la cinematografía es una forma válida de representar el pasado. Ahora bien, la representación sobre el pasado regularmente viene "desvirtuada" y dividida en tres aspectos temporales claramente diferenciables e inevitables dentro de la creación del filme: el distanciamiento entre el pasado evocado y el presente en el que se realiza el filme; los límites de la narrativa audiovisual que simplifican los hechos a un formato $y$ las posibles invenciones e intervenciones del cineasta ${ }^{16}$.

Con las anteriores precisiones en mente, el presente texto reflexiona acerca de cómo se representa en el largometraje Canaguaro la violencia colombiana de mediados del siglo, escenificada en los Llanos Orientales. De ahí que este ejercicio no pretenda verificar los hechos tal cual ocurrieron y fueron narrados fílmicamente ${ }^{17}$, sino que por medio del análisis de algunas

${ }^{15}$ Marc Ferro, Historia contemporánea y cine (Barcelona: Editorial Ariel S. A., 1995), 191-193.

${ }^{16}$ José Rueda Laffond y María Chicharro Merayo, "La representación cinematográfica: una aproximación al análisis sociohistórico", Ámbitos, n.․11-12 (2004): 433, http://hdl.handle. net $/ 11441 / 67670$.

${ }^{17}$ Mateus Mora, “Un cineasta chileno”, 37-38. La propuesta que precedió a la realización de Canaguaro era la filmación de un largometraje sobre el comandante guerrillero Guadalupe Salcedo, por lo que el equipo inició un proceso de investigación para la escritura del guion, consultando fuentes escritas, prensa de la época y entrevistas. Sin embargo, ante la dificultad de separar a la leyenda del ser real de Guadalupe Salcedo, se optó por una historia más general 
secuencias y escenas busca contrastarlas con la historiografía especializada del período de la violencia y la región. Para ello, en una primera parte se describe brevemente la metodología utilizada en el análisis cinematográfico y su puesta en funcionamiento. En la segunda parte el texto se adentra en el análisis del largometraje y su argumentación.

\section{El análisis cinematográfico: la metodología}

Para analizar la película seleccionada se hizo una pesquisa de tipo documental y un análisis de contenido a la luz de la historiografía especializada sobre el tema tratado en el filme. La primera fase se realizó mediante la puesta en funcionamiento de un instrumento de análisis secuencial de contenido fílmico que buscaba desglosar el largometraje en secuencias ${ }^{18}$ y estas a su vez en sus componentes narrativos más importantes ${ }^{19}$. Se debe resaltar que no todas las secuencias del largometraje fueron utilizadas, solo se seleccionaron aquellas en las cuales la argumentación tuvo como epicentro escenas relacionadas directamente con la violencia.

sobre la guerra en los Llanos Orientales. Es evidente que el guion y la misma actuación de los protagonistas se basó en el conocimiento que tenían como grupo de la violencia de mediados del siglo XX, en una especie de observación etnográfica del territorio, en entrevistas e investigación colectiva — propio de quienes se formaron en el Teatro La Candelaria de la mano de Santiago García y su propuesta de creación colectiva y crítica social—, dado que muchos de ellos pertenecían a la Escuela del Teatro La Candelaria.

${ }^{18}$ Martínez y Gómez, definen la secuencia como un fragmento del filme caracterizado por una sucesión de escenas y planos que engloban el desarrollo de una acción o situación dramática y que forma parte de la narración total que se plantea en el filme, según la acción que en ella se desarrolle y de su articulación con otras secuencias que le anteceden y suceden, la secuencia tiene una duración indeterminada. La imagen cinematográfica: manual de análisis aplicado (Madrid: Editorial Síntesis, 2015), 33.

19 Ángeles López Hernández, "El análisis cronológico-secuencial del documento fílmico", Documentación de las Ciencias de la Información, vol. 26, (2003): 265, https://revistas.ucm. es/index.php/DCIN/article/view/DCIN0303110261A. 
Figura 1. Análisis secuencial de contenido fílmico

\begin{tabular}{|c|c|c|c|c|c|c|c|c|c|}
\hline \multicolumn{10}{|c|}{ Análisis secuencial de contenido fílmico } \\
\hline Secuencia & Plano & Tiempo & Entorno & Luz & $\begin{array}{c}\text { Personajes/ } \\
\text { Caracterización }\end{array}$ & Acciones & Diálogos & $\begin{array}{l}\text { Música/ } \\
\text { Son. }\end{array}$ & Categorías \\
\hline
\end{tabular}

Fuente: Ángeles López Hernández, "El análisis cronológico-secuencial del documento fílmico” Documentación de las Ciencias de la Información vol. 26, (2003): 281, https://revistas.ucm.es/index.php/ DCIN/article/view/DCIN0303110261A.

La puesta en marcha de este instrumento para la fase documental se fundamentó inicialmente en tomar las secuencias en las que se dividía la película basándonos en el guion escrito, por medio de su lectura y la selección de las secuencias que cumplían con los parámetros establecidos previamente; y, después, en decidir cuáles secuencias se tendrían en consideración en la rejilla. Los parámetros o criterios se definieron a partir de categorías como violencia política, bipartidismo, Estado y guerrillas.

Una vez seleccionadas, las secuencias fueron dispuestas en la tabla para su posterior análisis. El desglose de las secuencias tuvo en cuenta los aspectos narrativos de las mismas por lo que cada una se dividió en los campos establecidos en la tabla consistentes en: planos, tiempo, luz, personajes, acciones y diálogos. Los aspectos narrativos que más se tuvieron en cuenta fueron aquellos de los diálogos ${ }^{20}$, de las acciones ejecutadas y de la utilización de los planos en los cuales nuestras categorías seleccionadas eran claramente identificables. Además, en la tabla de análisis fílmico fue adicionado un campo con las categorías establecidas con el fin de identificar más rápidamente el contenido de la secuencia.

Una vez organizadas las secuencias, el siguiente paso consistió en analizar su contenido basados en la historiografía especializada sobre el tema, para nuestro caso: la violencia en los Llanos Orientales durante el período de 1949 a 1953. Esto con la finalidad de comprender, según los planteamientos de la bibliografía especializada, cuál era el discurso sobre la violencia plasmado en dichas secuencias.

\footnotetext{
${ }^{20}$ Los diálogos fueron extraídos directamente del guion de Canaguaro, incluido en la compilación Cine de la Violencia (1987) realizada por Isabel Sánchez M.
} 


\section{Contexto argumental del filme}

Ante la llegada en 1946 de los conservadores al poder político y con el asesinato del caudillo liberal Jorge Eliécer Gaitán, el 9 de abril de 1948, el país se sumió en una ola inédita de violencia bipartidista cuyos orígenes se pueden remontar a 1930 cuando los conservadores se negaron a entregar el poder local y los liberales los perseguían ${ }^{21}$. La población liberal, amedrentada por el recién posesionado gobierno conservador, se organizó militarmente para defenderse de la persecución de que eran víctimas desde 1946, en una especie de "cruzada antiliberal y anticomunista ${ }^{22 "}$.

En ese contexto de persecución y exterminio surgen, en los Llanos Orientales y otras regiones, grupos guerrilleros organizados para contrarrestar a los agentes gubernamentales, pues la violencia contra la población campesina se enmarcó en un proyecto político de venganza y homogeneización partidista que significó un aumento del pie de fuerza estatal en regiones estratégicas de los Llanos: caminos, hatos, cabeceras municipales y puntos destinados al comercio $^{23}$.

Los llaneros se organizaron en autodefensas campesinas para proteger sus vidas y su patrimonio ante la arremetida de la policía conservadora, (llamada chulavita) y los militares afines al gobierno, quienes arrasaban a su paso las poblaciones, cultivos y pequeñas propiedades. Los comandos guerrilleros con un mando centralizado - por lo menos en los Llanos Orientales- se fueron organizando al calor de la guerra, hasta el punto que, en 1952, establecieron un programa político revolucionario ${ }^{24}$.

Al comienzo de las confrontaciones, la dirigencia de los comandos llaneros estuvo a cargo y contó con el apoyo de gamonales y hacendados liberales de la región (entre 1949 y 1951), interesados en la defensa y protección de su patrimonio y en mantener su posición dominante frente a sus peones. Un liderazgo resquebrajado a partir de 1951 con la Declaración de Sogamoso, pues

${ }^{21}$ Javier Guerrero Barón, Los años del olvido: Boyacá y los orígenes de la violencia (Tunja: UPTC, 2007), 30; Helwar Figueroa Salamanca, Tradicionalismo, hispanismo y corporativismo (Bogotá: Editorial Bonaventuriana, 2009), 92-93.

${ }^{22}$ Gonzalo Sánchez y Donny Meertens, Bandoleros, gamonales y campesinos: el caso de la violencia en Colombia (Bogotá: Ancora, 1984), 38.

${ }^{23}$ Reinaldo Barbosa Estepa, Guadalupe y sus centauros: memorias de la insurrección llanera (Bogotá: Cerec, 1992), 94-95.

${ }^{24}$ Germán Guzmán Campos, Orlando Fals Borda y Eduardo Umaña Luna, La Violencia en Colombia: estudio de un proceso social (Bogotá: Taurus, 2016), 71. 
allí se expresó la aspiración de los llaneros de a pie de mejorar sus condiciones de vida y sublevarse frente al trato de subordinación al que eran sometidos por parte de los hacendados-ganaderos, afines al liberalismo ${ }^{25}$, por lo cual los gamonales liberales desistieran de apoyar el movimiento guerrillero pues ponía en cuestión su poder, liderazgo y propiedades.

A partir de este punto, en 1952, los guerrilleros se autodenominaron Fuerzas Revolucionarias de los Llanos Orientales, con un número de hombres que alcanzó una cifra aproximada de 15.000 efectivos, quienes además promulgaron "La Primera Ley del Llano", producto de la conferencia guerrillera de septiembre de 1952 y que según algunos estudiosos se inspiró, hasta cierto punto, en la Revolución mexicana ${ }^{26}$. Aunque su centro fue la normatización de los derechos de sabana que permitían movilizar el ganado por todos los territorios, así como pastar libremente en los terrenos baldíos y que todos los vegueros pudiesen explotar las tierras colectivamente, en detrimento de los grandes hatos que se mostrasen improductivos o no apoyasen la revolución; también esta ley buscaba definir la administración de justicia y la independencia de las autoridades revolucionarias para ejercerla. Una propuesta revolucionaria profundizada con la Segunda Ley del Llano (18 de junio de 1953) pues en esta se definía el territorio de la revolución, su autonomía, la colectivización de la propiedad, la abolición del matrimonio, la democratización de las decisiones por medio de un gobierno popular, basado en las decisiones de la vereda y el ejercicio de la justicia, entre otras muchas propuestas revolucionarias ${ }^{27}$.

Conforme escalaba la violencia a nivel nacional y la guerrilla del Llano sumaba victorias, la élite bipartidista, previendo una pérdida de influencia sobre la peonada (pueblo), en 1953, orquestó — con el apoyo del Ejércitoel "golpe de Estado" protagonizado por el general Rojas Pinilla en contra del gobierno conservador de Laureano Gómez; de esta manera se buscó poner fin al enfrentamiento bipartidista que por aquellos años ya había costado la vida de alrededor de doscientos mil colombianos ${ }^{28}$. Ese mismo año se decretó una amnistía general para desarmar a los grupos guerrilleros de todo el país.

Si bien la mayoría de los grupos entregaron las armas, no significó un retorno a la paz, al contrario, se sucedió un nuevo ciclo de violencia movido

${ }^{25}$ Guzmán Campos, Fals Borda y Umaña Luna, La Violencia en Colombia, 71.

${ }^{26}$ Villamizar Herrera, Las guerrillas en Colombia, 148.

${ }^{27}$ Barbosa Estepa, Guadalupe y sus centauros, 176-231.

${ }^{28}$ Paul Oquist, Violencia, conflicto y política en Colombia (Bogotá: Biblioteca Banco Popular, 1978), 57. 
por la retaliación contra antiguos núcleos guerrilleros, pero también por la no realización de las aspiraciones sociales y el incumplimiento de las promesas gubernamentales, hecho que detonó la reactivación de antiguos focos subversivos. Así, tras la contienda, se dio un retorno a las formas de dominación previas al conflicto ${ }^{29}$. Es en este contexto que Canaguaro realiza con sus compañeros una travesía quimérica por los Llanos Orientales en búsqueda de unas armas prometidas y que el filme recrea de manera realista.

\section{Canaguaro: historia de una agresión y lucha popular}

El cartel con el que se anunció Canaguaro a principios de la década de los años ochenta estaba compuesto por una imagen de un llanero a caballo en actitud combativa, mientras en uno de sus brazos alzaba a lo alto un rifle; esta figura se sobreponía a la imagen del sol y a un paisaje que evoca el piedemonte llanero. Abajo, a la derecha, en el tercio inferior del cartel, se ve una imagen recortada de Jorge Eliécer Gaitán alzando su mano empuñada, acompañada de una frase que reza: "No era un hombre... era un pueblo!".

La razón por que estas dos imágenes aparentemente sin relación se funden en un solo mensaje está dada (más que por la intención de crear una analogía entre el caudillo liberal y el personaje ficticio del llanero a caballo) por la asociación del personaje individual - Canaguaro-y el personaje colectivo; es decir, el pueblo mismo, representado en la esperanza de un "revolucionario" (populista) que soñaba con una sociedad donde todos los hombres fueran iguales y libres. Y con la icónica frase de Gaitán, se abre al espectador la noción de que más que una historia individual, la película quiere resaltar que Canaguaro es la encarnación de un pueblo y su devenir en medio de la guerra.

${ }^{29}$ Barbosa Estepa, Guadalupe y sus centauros, 236. 
Figura 2. Cartel publicitario

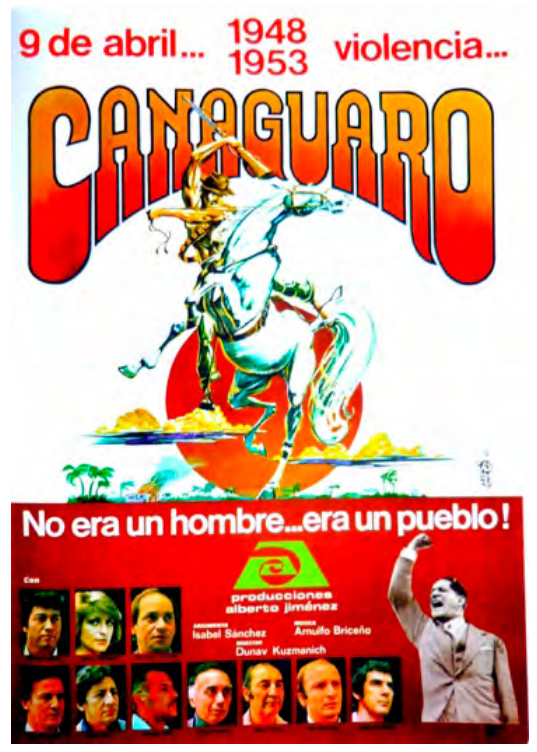

Fuente: https://www.proimagenescolombia.com/secciones/cine_colombiano/peliculas_colombianas/pelicula_plantilla.php?id_pelicula $=131$

La narración en off que abre la historia en el filme sitúa al espectador en el contexto político de mediados de siglo XX en Colombia; el tiempo que es una introducción a la representación que hace de la violencia y la evolución del movimiento guerrillero, que inicia desde una guerrilla con un rol meramente defensivo y con escasa dirección política hasta el surgimiento de un proyecto revolucionario:

El 9 de abril de 1948 es asesinado en Bogotá el líder popular Jorge Eliécer Gaitán. La Violencia, que hacía ya tiempo se abatía soterradamente sobre los campos de Colombia, se desata hora en Bogotá. La multitud se vuelca en las calles buscando en quién vengarse, en quien descargar su ira, a quién hacer pagar por la muerte de sus más caras esperanzas. Se inicia la llamada "época de la Violencia": una larga guerra que se arrastrará por 5 años en todo el ámbito de Colombia. Cientos de miles de muertos, atrocidades sin cuento, pueblos enteros desaparecidos bajo las llamas, familias que huyen sin saber a dónde, son el telón de fondo de una situación sin derrotero ni destino. El caos político encuentra salida en una guerra anárquica en la que el pueblo lucha porque se siente agredido, pisoteado, herido, aunque sin saber claramente qué es lo que busca, qué es lo que quiere, hacia dónde va... pero llegó el momento en que ese inmenso número de muertos del 
pueblo colombiano empezó a dar sentido a la lucha, empezó a señalar un camino, empezó a decir "basta ya”.

Y es así como en los Llanos Orientales se forma uno de los frentes más importantes de esa cruenta lucha por encontrar el camino hacia el destino del pueblo ${ }^{30}$.

Con la introducción del protagonista a la narración, la película empieza a evidenciar su visión sobre el movimiento armado surgido en los Llanos y su relación con el pueblo que lo conforma. La cámara enfoca su rostro en primer plano y se escucha su voz en off, que en la totalidad de la película se encargará de narrar los sucesos.

Figura 3. Primer plano de Canaguaro

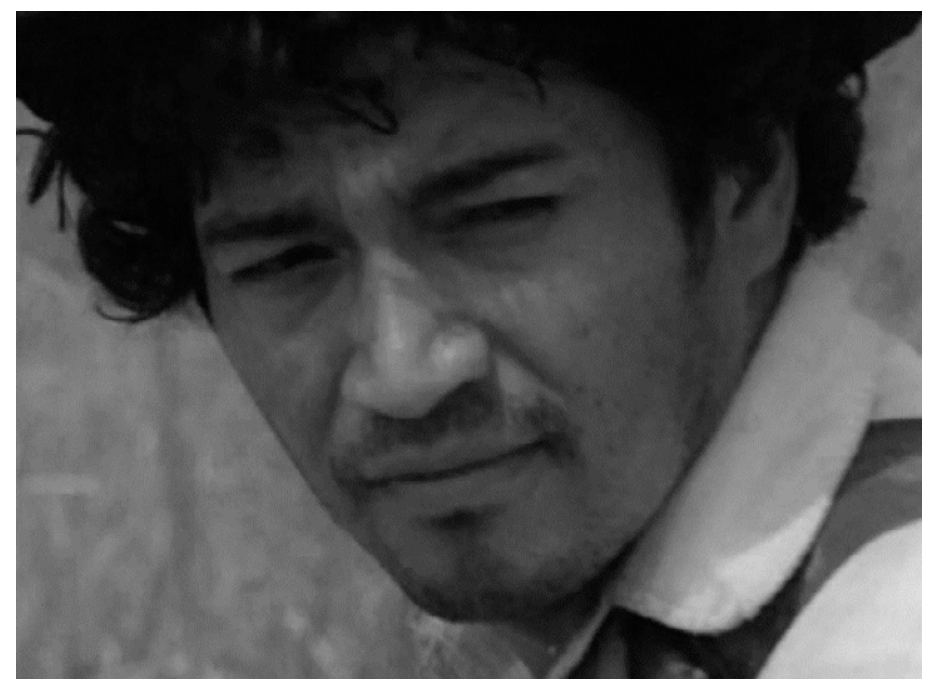

Fuente: Dunav Kuzmanich, dir., Canaguaro, (Bogotá: Producciones Alberto Jiménez, Corporación Financiera Popular Fonade, 1981), video disco digital (DVD), 87 min.

Los planos dotados de una función de conceder valor expresivo y narrativo a la historia - en este caso sugieren que la elección de este primer plano al rostro del protagonista, en sincronía con su narración- dicen al espectador que lo que se plantea es una visión del movimiento desde sí mismo; es decir, lo que Marc Ferro denominó un cine recreador de la historia desde abajo ${ }^{31}$.

${ }^{30}$ Dunav Kuzmanich et ál., "Canaguaro”, en Cine de la Violencia, comp. Isabel Sánchez M. (Bogotá: Universidad Nacional de Colombia, 1987), 21-22.

${ }^{31}$ Ferro, Historia contemporánea y cine, 196. 
En la siguiente escena, Canaguaro cabalga a través del llano y narra parte de su historia, evocando la esencia de los primeros momentos de lucha en la que el objetivo primordial era la guerra contra la policía y la defensa de la vida ${ }^{32}$.

CANAGUARO (Play Back): éramos ya muchos los alzados y lo único que faltaba para acabar con los chulavitas y ponerlos a correr para siempre eran armas y municiones (...) Yo me tenía que ir juntando por el camino con la gente de los otros comandos. Primero me fui al campamento del comandante Santos, que era el mandamás de los comandos del llano. Ahí tenía que recibir las instrucciones del propio comandante $(. .)^{33}$.

Esta imagen de un movimiento de autodefensa partidista se mantiene durante gran parte del largometraje. El historiador Eduardo Pizarro, para otro contexto, menciona que este tipo de guerrilla es condicionada por el proyecto político de determinado partido, el cual también regula sus actos ${ }^{34}$. En ese sentido, un diálogo entre el delegado del Partido Liberal y Canaguaro (en una escena posterior, en el campamento del comando) lo ilustra muy bien: por órdenes del partido, la misión de recoger las armas debe ser supervisada por los hacendados liberales (líderes de la zona), a lo que Canaguaro responde: "Claro que sí doctor. No hay ningún problema. Lo que la directiva mande ${ }^{35}$.

Esta obediencia de Canaguaro a la orden de los hacendados puede explicarse bajo lo expuesto por Justo Casas, quien nos recuerda cómo la sociedad llanera de mediados del siglo XX era fuertemente jerarquizada: era el oficio, entonces, el que determinaba el lugar en la pirámide social, cuya cima la ocupaba el propietario del hato, ausente la mayor parte del tiempo; más abajo se encontraban quienes realizaban oficios varios en la ganadería y la agricultura, hasta llegar al conuquero, quien apenas subsistía en la periferia de las haciendas. La jerarquía social en el mundo llanero dio lugar a una economía cercana a un régimen semifeudal ${ }^{36}$, de forma que la organización militar inicial del movimiento era una prolongación de la vida social del pueblo llanero; como

${ }^{32}$ Guzmán Campos, Fals Borda y Umaña Luna, La Violencia en Colombia, 66.

${ }^{33}$ Kuzmanich et ál., "Canaguaro”, 23.

${ }^{34}$ Eduardo Pizarro Leongómez, "Elementos para una sociología de la guerrilla en Colombia”, Análisis Político, n. ${ }^{\circ} 12$ (1991): 8, https://revistas.unal.edu.co/index.php/anpol/article/ view/74528.

${ }^{35}$ Kuzmanich et ál., "Canaguaro", 44.

${ }^{36}$ Justo Casas Aguilar, La Violencia en los Llanos Orientales (Comando de los hermanos Bautista) (Bogotá: Ecoe Ediciones, 1986), 42-43 
también se evidenció en las leyes del llano y su fuerte componente militarista. Nuestro protagonista era un fiel representante de esta situación.

En esa misma argumentación, Villanueva distingue dos clases de comandos guerrilleros: aquellos organizados por gamonales, colonos y pequeños propietarios, de los que sobresalieron los comandos de los hermanos Bautista, Fonseca y Aljure, entre otros; y otros formados por peones y llaneros, quienes se movían libremente por las sabanas y de donde salió la figura icónica de Guadalupe Salcedo ${ }^{37}$. La dependencia del Partido Liberal contribuyó a que la guerrilla careciese, durante la mayor parte de su existencia, de una orientación y programa político propio ${ }^{38}$, lo que suscitó su decaimiento pues el apoyo liberal se mantuvo apenas por dos años, luego de iniciado el conflicto.

Lo anterior permite interrogarnos por la violencia sistemática, la agresión a la que se vio sometida la población liberal de los Llanos y el papel del Estado colombiano en ello; en ese sentido vale preguntarse, ¿cómo se pone en escena la relación entre el Estado, el pueblo y la guerrilla liberal?

De allí que Agudelo resalte el interés del cine colombiano en denunciar la precariedad y ausencia del Estado en los territorios más vulnerables del país; especialmente en materia de violencia y control territorial ${ }^{39}$. No obstante, es posible dar con otras miradas en la cinematografía en las que el Estado se representa en su faceta violenta y represiva. En el caso de Canaguaro, la visión del Estado puede interpretarse en primer lugar a partir de una relación paradójica y excluyente, entre ausencia y presencia. Paradójica pues la ausencia de autoridades civiles de gobierno es notoria, en contraste con la presencia militar; excluyente, en la medida que el uso de la fuerza termina siendo protagonista en detrimento de la autoridad civil. El Estado hace presencia por medio de la fuerza en los territorios de frontera para controlarlos y en defensa de los intereses del partido político en el poder, en este caso de los conservadores ${ }^{40}$. En nuestro largometraje, el Estado se enfrenta abiertamente al pueblo por medio de los chulavitas - cuerpos armados irregulares provenientes de la vereda homónima en el departamento de Boyacá ${ }^{41}$ - y para el cual "[...] las bandas de chulavitas son pura y simplemente asimiladas al Ejército y a la Policía, con

37 Orlando Villanueva Martínez, Guadalupe Salcedo y la insurrección llanera, 1949-1957 (Bogotá: Universidad Nacional de Colombia, 2012), 153-157.

${ }^{38}$ Casas Aguilar, La Violencia en los Llanos Orientales, 47-48.

${ }^{39}$ Martín Agudelo Ramírez, Cine y conflicto armado en Colombia (Medellín: Unaula, 2016), 51.

${ }^{40}$ Barbosa Estepa, Guadalupe y sus centauros, 111.

${ }^{41}$ Sánchez y Meertens, Bandoleros, gamonales y campesinos, 38. 
lo cual se oculta la dimensión propiamente civil del conflicto entre "liberales" y “conservadores”, en sus aspectos ideológicos, político-ideológicos ${ }^{42}$ ”. Si bien el historiador Reinaldo Barbosa menciona la existencia de concentraciones del Ejército en los Llanos Orientales ${ }^{43}$, la película omite mencionarlo en todo momento y lo reemplaza a cabalidad por el término chulavita; adicionalmente, el atuendo y organización de estos se acerca más a una institución militar que a una agrupación de civiles armados. Esta homologación traslada la confrontación principalmente al plano de la represión y al antagonismo entre el Estado y el pueblo.

Figura 4. Chulavitas portando uniforme

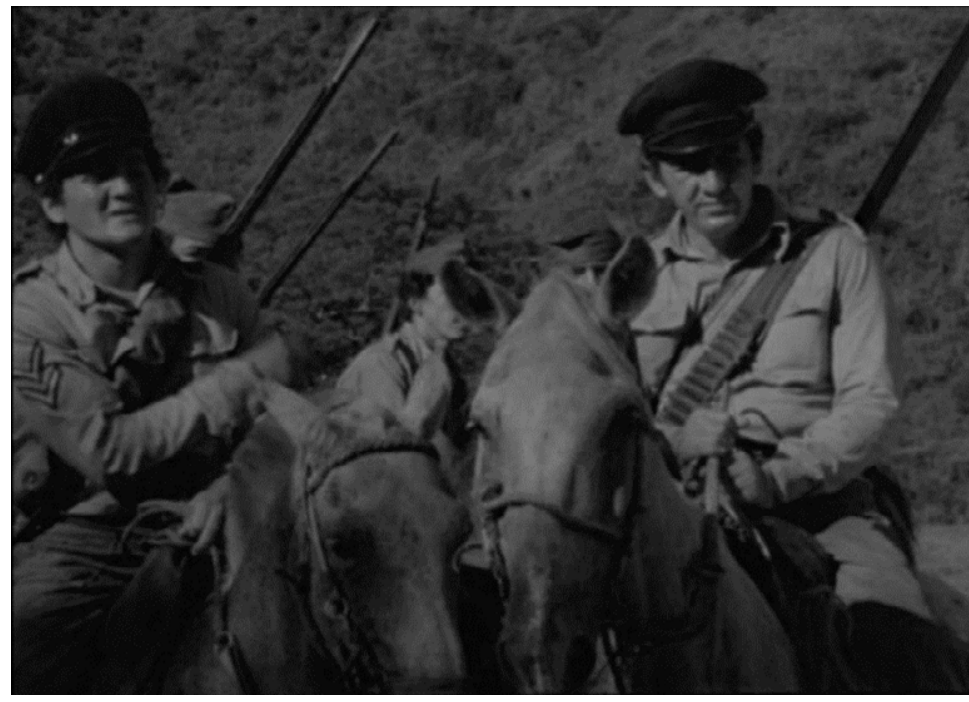

Fuente: Dunav Kuzmanich, Canaguaro.

Los chulavitas aparecen, por primera vez, en el relato de uno de los personajes - Antonio - quien se vio obligado a unirse a la guerrilla luego de una incursión chulavita en su pueblo natal. Un relato que reafirma la violencia inherente a las incursiones chulavitas y de militares a los pueblos liberales; sin embargo, son las palabras de su compañero y comandante, Canaguaro, las que evidencian de forma más clara la violencia sistemática perpetrada por parte del Estado.

\footnotetext{
${ }^{42}$ Mateus Mora, “Un cineasta chileno”, 41.

${ }^{43}$ Barbosa Estepa, Guadalupe y sus centauros, 108-112.
} 
CANAGUARO (Play Back): Con la conversa de Antonio se nos acortó el viaje (...) pero la verdad es que cosas como lo que me contó Antonio no eran ninguna novedad para mí (...)

CANAGUARO (Play Back): Así empezó, así creció y así siguió la violencia y por eso andábamos todos en lo que andábamos ${ }^{44}$.

El chulavita no es un habitante nativo del llano y si bien durante la violencia se conformaron grupos de contraguerrilla en el llano, los chulavitas que ingresaron en el territorio llanero provenían de las montañas de Boyacá. Inicialmente de la vereda Chulavita y después de todo el departamento, gracias a que los demás gobernadores alquilaban sus servicios, en un momento en que la Policía era departamental y resultaba más efectivo utilizar la de otras regiones para poder reprimir más fácilmente a la población nativa ${ }^{45}$. En diferentes escenas, la película explicita esto, pues en ellas se advierte la presencia del personaje del Culebrero - hombre correo con otras regiones del llano-, el cual sin saberlo guía las partidas chulavitas, quienes, tras seguirlo, entran violentamente a los pueblos en busca de guerrilleros. Escenas sobre las cuales se pone en evidencia el abandono del territorio llanero a mediados del siglo XX, pues el control ejercido vino principalmente de las incursiones militares ${ }^{46}$. Sin embargo, se debe resaltar con especial interés que en la película la campaña en el llano guarda más relación con una invasión; es decir, los chulavitas desconocen el territorio en el que se mueven y operan con gran desprecio por el pueblo llanero. Un ultraje que permite conocer la construcción del enemigo por parte del Estado. Sin embargo, para entender en la película cómo veían los chulavitas a sus enemigos en la guerra es necesario acercarse a la representación que estos se hacen de símismos, y de esta manera determinar qué consideran ellos como diferente. En primer lugar, existe una asimilación intrínseca entre el Partido Conservador y la religión católica. Una situación insistentemente llevada a escena cada vez que aparecen los chulavitas, los cuales son recreados como personajes taciturnos, violentos y religiosos. Por cierto, en la historia de los chulavitas sobresale la influencia que tuvo en su

\footnotetext{
${ }^{44}$ Kuzmanich et ál., "Canaguaro”, 29.

${ }^{45}$ María Uribe A., Matar, rematar y contramatar. Las masacres de la Violencia en el Tolima, 19481964 (Bogotá: Cinep, 1986) 54; Helwar Figueroa Salamanca, “Clérigos, parroquias y chulavitas. Norte de Boyacá. 1930-1946" (Tesis de pregrado, Universidad Nacional de Colombia, 1999), 50.

${ }^{46}$ Villanueva Martínez, Guadalupe Salcedo y la insurrección llanera, 151.
} 
vereda el conservatismo más reaccionario de Laureano Gómez y el discurso intransigente del cura Cayo Leonidas Peñuela, quien justificaba la persecución a los liberales por considerarlos ateos, masones y herejes ${ }^{47}$. Tres momentos de los muchos que hay en el filme sobre el elemento religioso ilustran esta situación; en el primero, se destacan los cantos religiosos y las cruces que se ven luego del incendio de un pueblo a manos de chulavitas. Las incursiones de esta índole las describe Reinaldo Barbosa de la siguiente manera: "Una gruesa columna al mando del capitán Alba avanzó peinando cuanto monte hubiese' al grito de ¡Viva Cristo Rey! ¡Mueran los rojos bandidos, enemigos de Dios! El bloqueo y las matanzas se generalizaron de nuevo por todo el llano adentro"48. En otra escena se observa el momento en que, antes de quemar la vivienda del protagonista (después de haber matado a su padre y violado a su madre y hermana), los chulavitas retiran un cuadro del Sagrado Corazón, alejándose con él y exponiéndolo mientras cabalgan; así el cuadro representa la devoción de los chulavitas por esta imagen; y, de paso, el director le recuerda al espectador el significado escatológico y nacionalista que tiene esta para Colombia. En efecto, la exposición directa de elementos religiosos, como parte de los personajes representantes del Estado, hace evidente la participación y complicidad de la Iglesia en los procesos de violencia política.

Figura 5. Chulavitas portan una cruz tras incendiar poblado

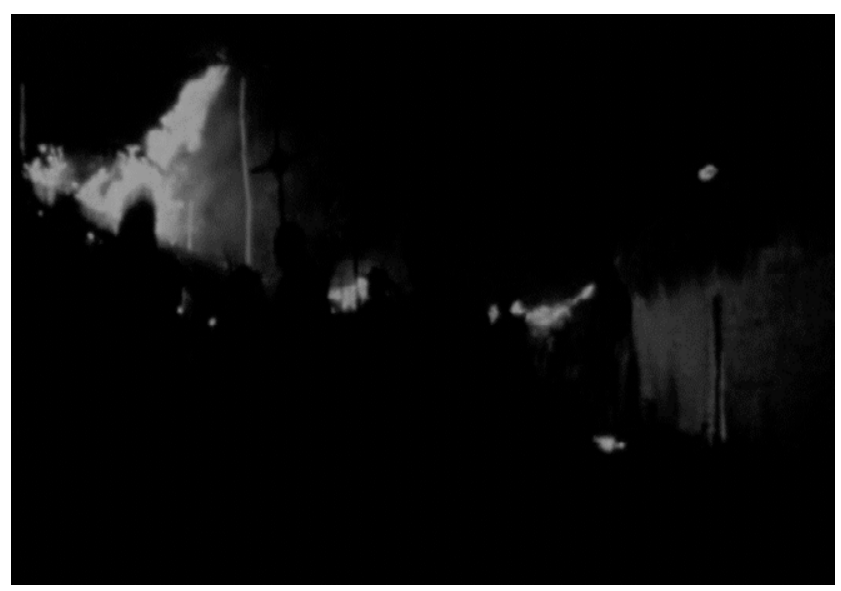

Fuente: Dunav Kuzmanich, Canaguaro.

\footnotetext{
${ }^{47}$ Figueroa Salamanca, "Clérigos, parroquias y chulavitas", 65.

${ }^{48}$ Barbosa Estepa, Guadalupe y sus centauros, 125.
} 
Figura 6. Chulavitas exhiben cuadro del Sagrado Corazón

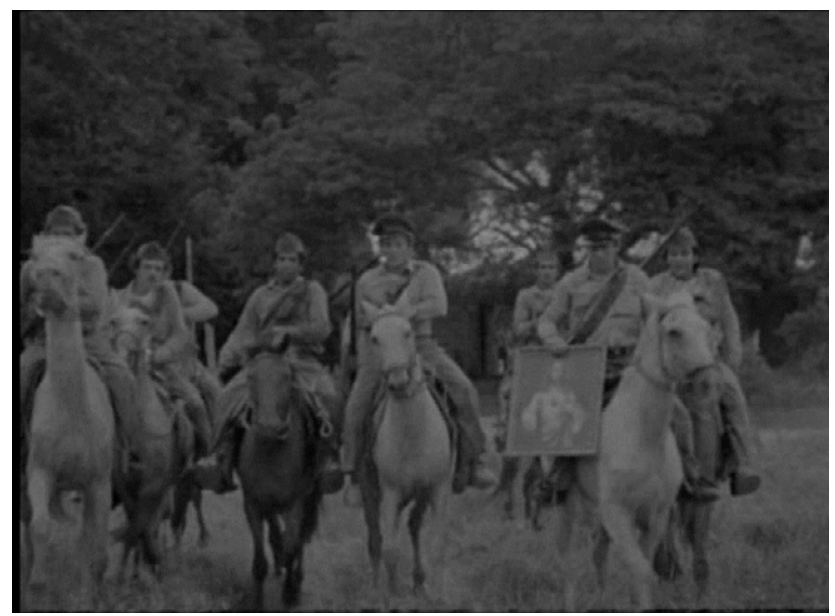

Fuente: Dunav Kuzmanich, Canaguaro.

No obstante, la escena más contundente sobre la relación violencia-religión la observamos en un sermón que realiza un cura frente al destacamento de Canaguaro, quien los invita a desmovilizarse: "a regresar al redil del Señor y en paz”. Al mismo tiempo, los guerrilleros leen un folleto que los invita a deponer las armas: "Paz, justicia y libertad, ofrece el Gobierno a los que depongan las armas". Ante la incredulidad y silencio de la columna, el cura entona Cantemos al amor de los amores. Los guerrilleros siguen en su búsqueda.

Señala Casas que el Gobierno ejerció la violencia por medio de la violencia física, la represión a las manifestaciones sociales y la coacción religiosa, pues la institución religiosa condenaba abiertamente al liberalismo y las luchas sociales $^{49}$. Además, el clero por esos años todavía era una autoridad políticoreligiosa a la cual se le debía respeto, sumisión y obediencia, a pesar de que en ese período la excomunión ya no amedrentaba tanto a los liberales, quienes también se consideraba católicos: se bautizaban, casaban y morían con los mismos ritos religiosos ${ }^{50}$.

En la película, la relación entre el conservatismo y el catolicismo sugiere que para estos el otro, el enemigo liberal, era ateo, masón y hereje, y, por tanto, se justifica su persecución y su muerte. Esta confrontación, en torno a la cuestión

${ }^{49}$ Casas Aguilar, La Violencia en los Llanos Orientales, 19.

${ }^{50}$ María Cifuentes y Helwar Figueroa Salamanca, "Corrientes del catolicismo frente a la guerra y la paz en el siglo XX”, en Historia del cristianismo en Colombia. Corrientes y diversidad, coord. Ana María Bidegaín (Bogotá: Taurus, 2004), 373-420. 
religiosa - que hunde sus raíces en las luchas bipartidistas del siglo XIX — se vio acrecentada con las reformas liberales de los años treinta que le quitaron privilegios constitucionales a la Iglesia, y con su cercanía a los movimientos sociales de la época, puesto que estas reformas ponían en cuestión la autoridad eclesiástica. La respuesta por parte de la institución eclesiástica fue retomar la intransigencia decimonónica. Además, esta postura dentro del conservatismo fue radicalizada por personajes como Laureano Gómez y sus constantes acusaciones contra las ideas liberales, a las cuales culpabilizaba — de la mano de monseñor Miguel Ángel Builes - de ser responsables de la pérdida de los valores cristianos y de la llegada de filosofías contrarias a la fe $\mathrm{f}^{51}$.

El filme propone las supuestas diferencias político-religiosas de sus protagonistas; sin embargo, a partir de dos planos similares que aparecen en contextos diferentes, termina por enunciar lo contrario: conservadores y liberales son creyentes. Aún más, a pesar de que ambos se reconozcan a sí mismos como adscritos a una facción política diferente, pertenecen a la misma clase social, profesan el mismo culto y viven en el país del Sagrado Corazón. Un símbolo religioso de gran poder devocional que representa el amor y la entrega de Jesús por la salvación de los hombres, y al cual se consagraba el país desde el siglo XIX cada vez que se acababa una guerra civil, sacándole en procesión para rezar por la paz; un símbolo que también acompañaba a los ejércitos en medio de las confrontaciones militares, como se muestra en el filme ${ }^{52}$.

El primer plano muestra a una familia conservadora rezando ante un cuadro del Sagrado Corazón y el segundo - donde aparece la familia del protagonista en un plano amplio de un cuarto de la casa familiar-muestra el mismo cuadro del Sagrado Corazón, ante el cual la joven hermana del protagonista (liberal) se persigna, poco antes de que los chulavitas quemen la casa, asesinen a su familia y se lleven la imagen sagrada como símbolo de triunfo.

\footnotetext{
${ }^{51}$ Figueroa Salamanca, Tradicionalismo, hispanismo y corporativismo, 93; Helwar Figueroa Salamanca, "Monseñor Miguel Ángel Builes, un político intransigente y escatológico (19251950)", Anuario de Historia Regional y de las Fronteras vol. 21, n. 1 (2016): 248, https://doi. org/10.18273/revanu.v21n1-2016009

${ }^{52}$ Figueroa Salamanca, Tradicionalismo, hispanismo y corporativismo, 73.
} 
Secuencias de una guerra: Representación de la violencia en los llanos orientales en el largometraje Canaguaro (1981) Jairo Alberto Tamí Rincón - Helwar Hernando Figueroa Salamanca

Figura 7. Sagrado Corazón en casa conservadora

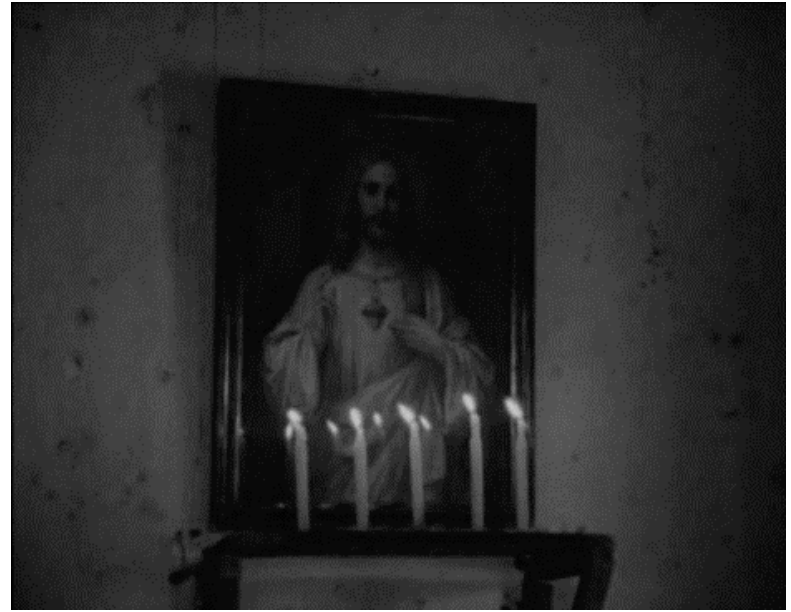

Fuente: Dunav Kuzmanich, Canaguaro.

Figura 8. Familia conservadora reza ante cuadro del Sagrado Corazón

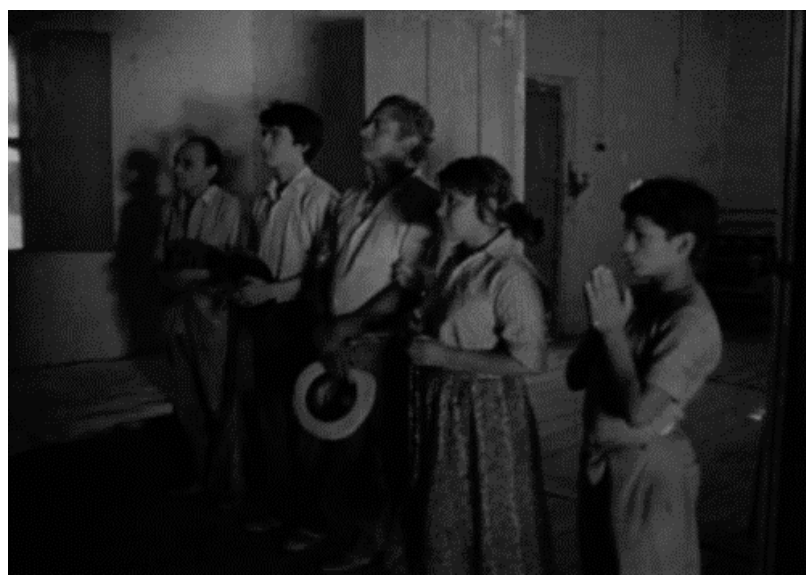

Fuente: Dunav Kuzmanich, Canaguaro. 
Figura 9. Familia liberal reza ante el mismo cuadro

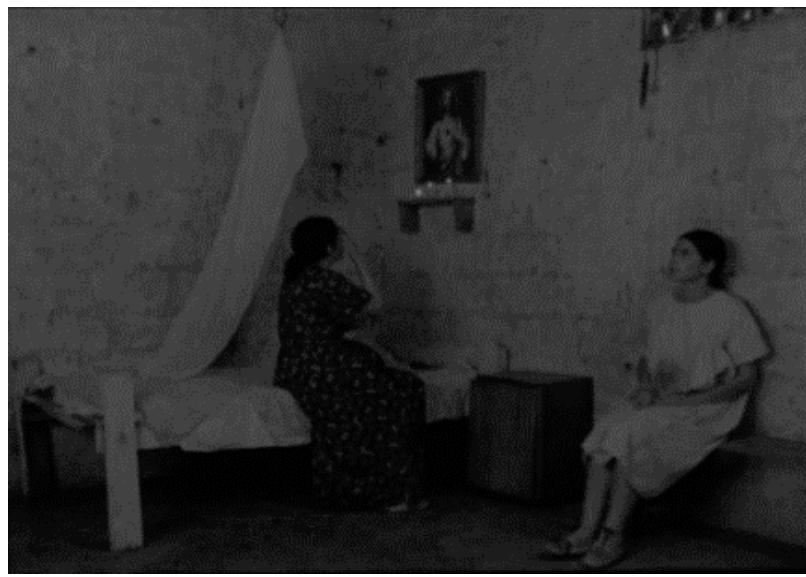

Fuente: Dunav Kuzmanich, Canaguaro.

Esta puesta en escena puede interpretarse como la intención de resaltar la idea de que el pueblo es uno solo, haciendo a un lado los odios heredados, que comparte costumbres arraigadas de tiempo atrás. Cuando surgen las divisiones se agrede a sí mismo como consecuencia de una división impuesta desde arriba. De ahí que el propósito central de la película es hacer énfasis en la confrontación Estado-Pueblo, lo cual permite observar la evolución de un movimiento que, en un principio, estuvo bajo el control de una élite, y que se aleja cuando toma conciencia de la situación en la que se encuentra inmerso y de las posibilidades de constituirse en un movimiento autónomo. En efecto, el alejamiento frente a la élite liberal obedeció a que los grupos armados hallaron diferentes formas de organización que pusieron en tela de juicio la dependencia y la lealtad partidistas, yendo en contravía de los intereses de los hacendados de ambos partidos - de mantener bajo su tutela a los grupos armados- pues, al poder de los líderes políticos en la capital o de los hacendados en las zonas de conflicto, se anteponía el mando de los líderes guerrilleros de extracción campesina $^{53}$, una decisión popular evidente al leer las mencionadas leyes de los llanos.

En ese sentido, la película se acerca a la última etapa sobre la evolución del movimiento guerrillero - es decir, su etapa revolucionaria - y su ruptura definitiva con la dirección liberal. El personaje encargado de materializar

${ }^{53}$ Fernando Guillén Martínez, El poder político en Colombia (Bogotá: Editorial Planeta Colombiana S. A., 2008), 458. 
dicha posición es el Profe, quien plantea esta posibilidad en una línea durante un diálogo que sostiene con una habitante de un caserío por el que pasan en búsqueda de las armas:

CARMEN: (...) El chino mío, ahí se quedó a medio camino en todo. El taita me lo mataron y el pobre muchacho anda sin saber qué camino agarrar (...) (Dirigiéndose al profe) (...) Por eso la gente lo ha echado tanto de menos, Profe.

PROFE: Ya habrá tiempo, misiá Carmen (...) Pero primero hay que cambiar esta vaina o si no para qué carajos sirve lo que yo enseñe $(. . .)^{54}$.

La película confronta dos proyectos de país distintos: mientras en las palabras del Profe hay una intención de transformación, por el otro lado, la élite liberal pugna por el statu quo; de modo que la estrategia inicial del odio heredado, como menciona Guillén, se vuelve contra las élites que previamente habían hecho uso de él para el mantenimiento de las lealtades ${ }^{55}$. Este proyecto alternativo de país se observa más adelante en la figura popular de Guadalupe Salcedo, quien aparece en una escena tras la representación de un combate y la toma del pueblo de Páez por parte de la guerrilla de los Llanos. Guadalupe, a quien se consideró el guerrillero más emblemático de la guerra en los Llanos y alcanzó el estatus de leyenda entre la población ${ }^{56}$, es en la película el portavoz de la visión que la guerrilla crea sobre sí, y de su intención de formular un cambio profundo a partir de su insurrección armada. Al final de la escena, declara:

GUADALUPE: Nosotros no somos criminales; no matamos a los prisioneros ni violamos a sus mujeres; respetamos sus vidas. Nos llevaremos el uniforme y las armas. Por unos días Páez estará libre de chulavitas.

GUADALUPE: (Dirigiéndose a los policías presos) Quiero que ustedes sepan, lo mismo que todos los habitantes de aquí de Páez, que no somos bandoleros, que luchamos por una patria libre, donde todos seamos

\footnotetext{
${ }^{54}$ Kuzmanich et ál., "Canaguaro”, 51.

${ }^{55}$ Guillén Martínez, El poder político en Colombia, 465.

${ }^{56}$ Villanueva Martínez, Guadalupe Salcedo y la insurrección llanera, 457-481.
} 
iguales, tengamos las mismas oportunidades, donde todos vivamos como hermanos ${ }^{57}$.

Figura 10. Guadalupe Salcedo

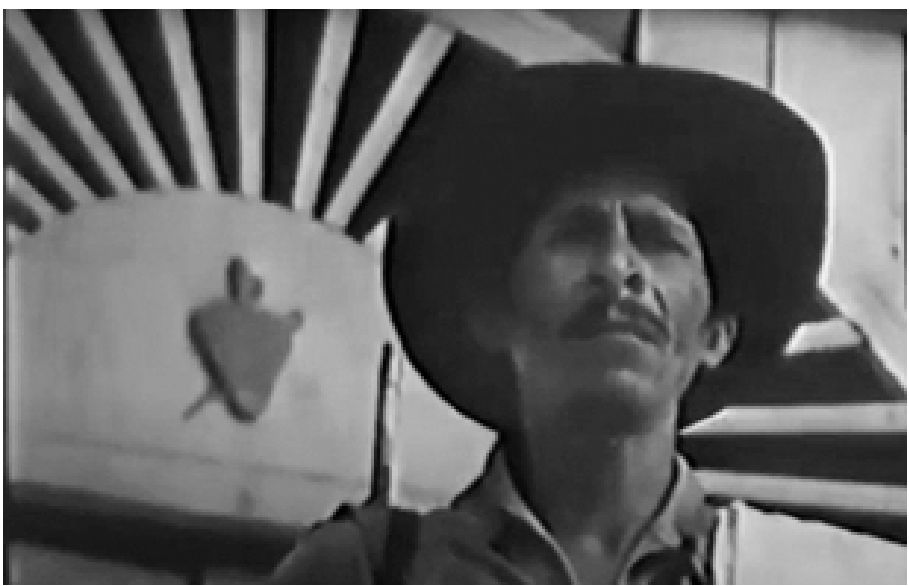

Fuente: Dunav Kuzmanich, Canaguaro.

Cerca del final de la película, el delegado del Partido Liberal anuncia ante los combatientes un nuevo Gobierno y las promesas de amnistía y cambio para los guerrilleros que entreguen las armas. Los hacendados liberales que acompañan al grupo acatan las órdenes arrojando simbólicamente sus revólveres al suelo y se llevan consigo a la mayoría de los hombres del escuadrón. Solo tres se niegan a hacerlo, entre ellos Canaguaro y el Profe, quien afirma lo siguiente:

PROFE: ¡Mire, doctor Vargas! (...) Yo creo que nosotros no hemos peleado para volver a la vida de antes (...) ¿o usted sabe cómo era la vida de antes de nosotros? (...) hambre, sufrimiento, miseria (...) y con lo que acaba de decir es cuando más tenemos que ganar, porque vamos a seguir peleando (...) $\mathrm{O}$ es que usted cree que Gabriela puede volver a la vida de antes (...) o que Canaguaro puede resucitar a sus padres, que murieron (...) Ya Antonio ni pueblo tiene, porque ya no existe (...) Se lo quemaron (...) Yo no puedo ir a una escuela a enseñar a los guámbitos, diciéndoles: no, si en este país todo marcha bien. ¡No señor! (...) y escúcheme bien una cosa, doctor... aquí esto lo hablamos nosotros, lo decidimos nosotros, ¿entiende? $(. . .)^{58}$.

\footnotetext{
${ }^{57}$ Kuzmanich et ál., "Canaguaro”, 64 .

${ }^{58}$ Kuzmanich et ál., "Canaguaro”, 74.
} 
En cuanto a la traición de la élite liberal, el filme ilustra que son los hacendados liberales los primeros en acatar las órdenes, por lo que simbólicamente el hacendado arroja su pistola en señal de deponer la armas; sin embargo, la toma de nuevo cuando se aleja en compañía del delegado del Partido en la lancha que los transporta y dándole la orden a uno de sus peones: "chino, lleve el caballo". Más adelante van a ser los mismos hacendados liberales quienes prestan sus recursos y armas para dar caza a los guerrilleros que habían decidido no entregar las armas. Lo anterior puede recogerse en lo expuesto por Justo Casas al mencionar que, tras las escisiones, se da comienzo a una lucha ya no entre las facciones partidistas, sino entre la élite y el campesinado ${ }^{59}$.

Las líneas de Canaguaro, cerca del final del filme, al alejarse cabalgando con sus compañeros que no entregaron las armas, sentencian lo que fue la política del Estado y la situación de los excombatientes una vez decidieron acogerse al proceso de amnistía: "uno a uno, mataron a los compañeros de Canaguaro que creyeron en la amnistía y entregaron las armas ${ }^{60}$ ".

En esta escena se aprecia a Canaguaro y a dos de sus compañeros cabalgando hacia el horizonte de la sabana e internándose en el monte, intercalada de imágenes de asesinatos de antiguos miembros de la guerrilla - en una de ellas se recrea el asesinato de Guadalupe Salcedo ocurrido el 6 de junio de 1957 en una calle oscura de Bogotá (llama la atención la similitud que tiene con la escena de la muerte del cóndor en el filme Cóndores no entierran todos los días) -; con ello se busca evidenciar la naturaleza cíclica de la guerra en Colombia. El filme no concluye, es el preludio de un nuevo ciclo de violencia que invita al espectador a inferir que la guerra y los problemas sociales continúan. Canaguaro y sus compañeros de armas cabalgan llano adentro, conscientes de su destino y con la esperanza de seguir en la brega de la búsqueda de verdaderos cambios sociales que acaben con la pobreza del pueblo y el sometimiento de los que son víctimas.

\footnotetext{
${ }^{59}$ Casas Aguilar, La Violencia en los Llanos Orientales, 43-44

${ }^{60}$ Kuzmanich et ál., "Canaguaro”, 78.
} 
Figura 11. Canaguaro escapa con sus compañeros tras no entregar sus armas

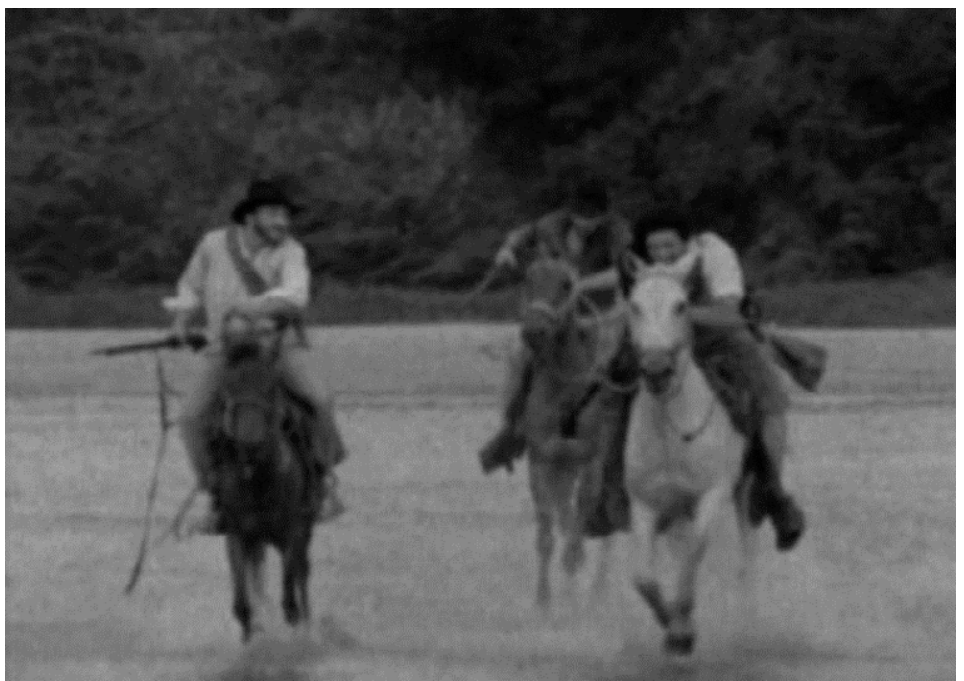

Fuente: Dunav Kuzmanich, Canaguaro.

\section{Conclusiones}

Como es sabido, las fuerzas armadas iniciaron una nueva ola de violencia contrala población civil y los excombatientes, yjunto a grupos contrainsurgentes se dieron a la tarea de diezmar a quienes reclamaban el incumplimiento de las promesas y defendían los intereses de los llaneros ${ }^{61}$. Vale la pena recordar la relación entre el cartel publicitario y la visión propuesta por la película sobre el movimiento guerrillero. Durante el análisis se sugirió la evolución de la guerrilla de una primera etapa partidista y de autodefensa, hasta constituirse como proyecto social autónomo. Con los personajes de Canaguaro y el Profe se aprecia esta transición de la lealtad partidista hacia la lucha popular, situación que afrontaron los diversos núcleos guerrilleros en diversas regiones del país.

"No era un hombre... era un pueblo", más que una evidente referencia a Gaitán y al levantamiento del 9 de abril de 1948, funciona como analogía para entender el rol y la evolución de Canaguaro y el Profe, depositarios de la representación de un actor colectivo, el pueblo. Más que individuos encarnan el sentir de una parte de la sociedad que lucha abiertamente por una transformación en sus condiciones de vida.

${ }^{61}$ Barbosa Estepa, Guadalupe y sus centauros, 241. 
La película por sí sola constituye un balance de la violencia en Colombia; si bien se ubica en un contexto regional, sus eventos pueden extrapolarse a otras regiones del país. En ese sentido, el argumento tiene el detonante del asesinato de Gaitán que justifica el levantamiento mostrado al inicio de la película y continúa con una síntesis del modo en que se desarrolló la guerra ilustrando el vaivén de los ataques y de las retaliaciones cometidas; como lo señala Barbosa, en la cual, a los ataques de chulavitas, les seguían los ajustes de cuentas de parte de los comandos, reiniciando el ciclo ${ }^{62}$. A esto se suma el cambio de horizonte del movimiento guerrillero y su escisión de la dirigencia política tradicional, y el nacimiento de una nueva ola de violencia.

En el filme se aborda la problemática de la Violencia a partir de la idea de la lucha de clases y un enfrentamiento entre el pueblo y el Estado, el cual se hace más evidente conforme el argumento se acerca a su final. Esta confrontación Estado-pueblo es notoria por la homologación entre las fuerzas irregulares de chulavitas y el Ejército, y por la necesidad primordial de autodefensa de las primeras fases de la guerrilla, lo que desplaza la confrontación civil al plano de la represión estatal.

Así mismo, la intención de crear una analogía entre Canaguaro y el pueblo es un intento de construir un héroe de la lucha popular campesina, similar a como ocurre con iconos latinoamericanos como Pancho Villa y Emiliano Zapata en la Revolución mexicana; por cierto que la cinematografía contribuyó a instaurarlos como representantes del sentimiento popular, libertario y campesino $^{63}$.

En relación con el Estado, más allá de señalar su ausencia política, el filme pretende mostrar su carácter represivo y de abierta confrontación, motivado por intereses sectarios; así la ausencia estatal es sustituida por la presencia militar y violenta. Los chulavitas — representantes del Estado — son asimilados a las fuerzas oficiales del Estado y son vistos como intransigentes, en alusión a la comunión Estado-Iglesia. Al finalizar, la Violencia, o mejor la guerra civil de mediados del siglo XX, se superó por medio de la ratificación de la consagración del país al Sagrado Corazón de Jesús, y, en 1957, con la refrendación de la

${ }^{62}$ Barbosa Estepa, Guadalupe y sus centauros, 88.

${ }^{63}$ Ricardo Pérez Montfort, "Antecedentes del estereotipo revolucionario y su presencia en los inicios del cine de ficción mexicano”, en La Revolución mexicana en el cine: un acercamiento a partir de la mirada italoeuropea, coord. Bernd Hausberger y Raffaele Moro (México D. F.: El Colegio de México, Centro de Estudios Históricos, 2013), 44-45. 
religión católica como la oficial de la Nación - frase que encabezaba el plebiscito de 1957 que estableció el Frente Nacional-.

Por último, la guerrilla liberal de los Llanos Orientales en sus inicios asumió una actitud de obediencia partidista, pero evolucionó en medio de la confrontación hacia una posición política clasista identificada con el campesinado. Ahí se rompe con el modelo de guerra bipartidista y se radicaliza la confrontación armada pues salen a flote los problemas sociales del país, un momento seminal que abre el escenario político a una nueva violencia.

\section{Bibliografía}

\section{Fuentes primarias}

Kuzmanich, Dunav et ál. "Canaguaro”. En Cine de la Violencia, compilado por Isabel Sánchez M. Bogotá: Universidad Nacional de Colombia, 1987.

Kuzmanich, Dunav, dir.. Canaguaro. Bogotá: Producciones Alberto Jiménez, Corporación Financiera Popular Fonade, 1981. Vídeo disco digital (DVD), 87 min.

\section{Fuentes secundarias}

Acosta, Luisa. "Investigación sobre cine en Colombia: de aficionados a cibernautas". Cuadernos de Cine Colombiano, n. 13 (2009): 22-37, https://idartesencasa.gov. co/artes-audiovisuales/libros/cuadernos-de-cine-colombiano-no-13-investigacion-e-historiografia

Acosta, Luisa. “El cine colombiano sobre la Violencia 1946-1958”. Signo yPensamientovol. 17, n. ${ }^{\circ} 32$ (1998): 29-40, https://revistas.javeriana.edu.co/index. php/signoypensamiento/article/view/3023

Agudelo Ramírez, Martín. Cine y conflicto armado en Colombia. Medellín: Unaula, 2016.

Archila Neira, Mauricio. “Colombia 1975-2000: de crisis en crisis. Contexto”. En 25 años de luchas sociales en Colombia: 1975-2000, editado por Helena Gardeazábal Garzón. Bogotá: Ediciones Anthropos Ltda., 2002, 11-43.

Barbosa Estepa, Reinaldo. Guadalupe y sus centauros: memorias de la insurrección llanera. Bogotá: Cerec, 1992.

Barón Pino, María y Camilo Ordóñez Robayo, "Editoriales visuales, publicidad gráfica y cine al final del Frente Nacional”. Cuadernos de música, artes visuales y artes escénicas vol. 6, n.. 2 (2011): 117-151, https://doi.org/10.11144/Javeriana. mavae6-2.evpg

Burke, Peter. Visto y no visto: el uso de la imagen como documento histórico. Barcelona: Editorial Crítica, 2005.

Casas Aguilar, Justo. La Violencia en los Llanos Orientales (Comando de los hermanos Bautista). Bogotá: Ecoe Ediciones, 1986. 
Castellanos, Gonzalo. Cinematografía en Colombia: tras las huellas de una industria. Bogotá: Icono Editorial, 2014.

Cifuentes, María y Helwar Figueroa Salamanca, "Corrientes del catolicismo frente a la guerra y la paz en el siglo XX”. En Historia del cristianismo en Colombia. Corrientes y diversidad, coordinado por Ana María Bidegaín. Bogotá: Taurus, 2004. 373-419.

Ferro, Marc. Historia contemporánea y cine. Barcelona: Editorial Ariel S. A., 1995.

Figueroa Salamanca, Helwar. "Clérigos, parroquias y chulavitas. Norte de Boyacá. 1930-1946”. Tesis de pregrado, Universidad Nacional de Colombia, 1999.

Figueroa Salamanca, Helwar. "Monseñor Miguel Ángel Builes, un político intransigente y escatológico (1925-1950)”. Anuario de Historia Regional y de las Fronteras vol.21, N. 1 (2016): 237-259, https://doi.org/10.18273/revanu.v21n1-2016009

Figueroa Salamanca, Helwar. Tradicionalismo, hispanismo y corporativismo. Una aproximación a las relaciones non sanctas entre religión y política en Colombia (1930-1952). Bogotá: Editorial Bonaventuriana, 2009.

Franco Restrepo, Vilma. Orden contrainsurgente y dominación. Bogotá: Siglo del Hombre, 2009.

González, Fernán, Ingrid Bolívar y Teófilo Vázquez. Violencia política en Colombia: de la nación fragmentada a la construcción del Estado. Bogotá: Cinep, 2003.

Guerrero Barón, Javier. Los años del olvido: Boyacá y los orígenes de la violencia. Tunja: UPTC, 2007.

Guillén Martínez, Fernando. El poder político en Colombia. Bogotá: Editorial Planeta Colombiana S. A., 2008.

Guzmán Campos, Germán, Orlando Fals Borda y Eduardo Umaña Luna. La Violencia en Colombia: estudio de un proceso social. Bogotá: Taurus, 2016.

León Palacios, Paulo. "Una experiencia estética de lo político: el teatro en Bogotá durante los años 1960 y 1970”. Historelo vol. 9, n. 17 (2017): 49-83, https://doi. org/10.15446/historelo.v9n17.54732.

López Hernández, Ángeles. "El análisis cronológico-secuencial del documento fílmico”. Documentación de las Ciencias de la Información, vol. 26 (2003): 261-294, https://revistas.ucm.es/index.php/DCIN/article/view/DCIN0303110261A.

Martínez García, María y Antonio Gómez Aguilar. La imagen cinematográfica: manual de análisis aplicado. Madrid: Editorial Síntesis, 2015.

Martínez Pardo, Hernando. Historia del cine colombiano. Bogotá: Editorial Guadalupe, 1978.

Mateus Mora, Angélica. "Un cineasta chileno. Kuzmanich y el cine de la Violencia en Colombia”. Revista CUHSO, vol. 14 (2007): 35-42 , http:/dx.doi.org/10.7770/ cuhso-V14N1-art262

Oquist, Paul. Violencia, conflicto y política en Colombia. Bogotá: Biblioteca Banco Popular, 1978.

Ortiz Sarmiento, Carlos. "Historiografía de la Violencia”. En Historia al final del milenio. Ensayos de historiografía colombiana y latinoamericana. Bogotá: Universidad Nacional de Colombia, 1994. 
Osorio, Oswaldo. "Historiografía del cine colombiano. La saga atrasada de un cine que camina lento”. Cuadernos de Cine Colombiano, n. 13 (2009): 6-21, https:// idartesencasa.gov.co/artes-audiovisuales/libros/cuadernos-de-cine-colombiano-no-13-investigacion-e-historiografia

Pérez Montfort, Ricardo. "Antecedentes del estereotipo revolucionario y su presencia en los inicios del cine de ficción mexicano”. En La Revolución mexicana en el cine: un acercamiento a partir de la mirada italoeuropea, coordinado por Bernd Hausberger y Raffaele Moro. México D. F.: El Colegio de México, Centro de Estudios Históricos, 2013. 38-57.

Pizarro Leongómez, Eduardo. "Elementos para una sociología de la guerrilla en Colombia”. Análisis Político, n. ${ }^{\circ} 12$ (1991): 7-22, https://revistas.unal.edu.co/index. php/anpol/article/view/74528.

Pulecio, Enrique. "Cine y violencia en Colombia”. En Arte y violencia, editado por Álvaro Medina. Bogotá: Museo de Arte Modeno de Bogotá, 1999.

Romero Vidal, Mauricio. Paramilitares y autodefensas, 1982-2003. Bogotá: Planeta, 2003.

Rueda Laffond, José y María Chicharro Merayo. “La representación cinematográfica: una aproximación al análisis sociohistórico”. Ámbitos, N. 11-12 (2004): 427-450, http://hdl.handle.net/11441/67670.

Sánchez, Fernando Fabio y Gerardo García Muñoz, La luz y la guerra. El cine de la Revolución mexicana. México D. F.: Dirección de Publicaciones del Consejo Nacional para la Cultura y las Artes, 2010.

Sánchez, Gonzalo y Donny Meertens. Bandoleros, gamonales y campesinos: el caso de la violencia en Colombia. Bogotá: Ancora, 1984.

Sánchez, Gonzalo y Ricardo Peñaranda, (compiladores). Pasado y presente de la violencia en Colombia. Bogotá: Cerec, 1987.

Suárez, Juana. Cinembargo Colombia: ensayos críticos sobre ciney cultura. Cali: Editorial Universidad del Valle, 2009.

Suárez, Juana. Sitios de contienda: producción cultural colombiana y discurso de la violencia. Madrid: Iberoamericana, 2010.

Uribe A., María. Matar, rematary contramatar. Las masacres de la Violencia en el Tolima, 1948-1964. Bogotá: Cinep, 1986.

Villamizar Herrera, Darío. Las guerrillas en Colombia. Una historia desde los orígenes hasta los confines. Bogotá: Penguin Ramdom House Grupo Editorial, 2017.

Villamizar, Juan Carlos. "Elementos para periodizar la violencia en Colombia: dimensiones causales e interpretaciones historiográficas”. Ciencia política vol. 13, n. 25 (2018): 173-198, https://doi.org/10.15446/cp.v12n25.65251.

Villanueva Martínez, Orlando. Guadalupe Salcedo yla insurrección llanera, 1949-1957. Bogotá: Universidad Nacional de Colombia, 2012.

Villegas, Andrés y Santiago Alarcón. "Historiografía del cine colombiano 19752015”. HISTOReLo, vol. 9, n.. 18 (2017): 344-382, https://doi.org/10.15446/ historelo.v9n18.58785 
